\title{
How can ecological urbanism promote human health?
}

\author{
Como o urbanismo ecológico pode promover a saúde humana?
}

Laís Fajersztajn ${ }^{[a]}$, Nilmara de Oliveira Alves ${ }^{[a]}$, Micheline de Souza Zanotti Staglionario Coelho ${ }^{[a, b]}$, Mariana Matera Veras ${ }^{[a, c]}$, Paulo Hilário Nascimento Saldiva ${ }^{[a, c]}$

\footnotetext{
[a] Universidade de São Paulo (USP), Faculdade de Medicina, Departamento de Patologia, Laboratório de Poluição Atmosférica Ambiental (LIM05), São Paulo, SP, Brasil

[b] Center for Air Quality and Health Research and Evaluation, Sydney, Australia

[c] Instituto Nacional de Análise Integrada do Risco Ambiental (INAIRA), São Paulo, SP, Brasil
}

\section{Abstract}

This special issue of URBE dedicated to Ecological Urbanism focuses on the role architects, landscape designers and urban planners can play in promoting healthier cities in Latin America. In this paper, we survey some of the empirical evidence that links the built environment with particular health outcomes. For many centuries, urban settlements were associated with adverse health outcomes, especially related to untreatable epidemics. As the science of disease transmission developed throughout the nineteenth century, the infrastructure of cities was transformed to promote improved public health. Significant gains were made, but in much of the world - Latin America included - urban health still remains a major challenge, all the more so as drug resistant strains of disease have become more prevalent. We believe Ecological Urbanism offers a promising framework for addressing these challenges. Distinguished by its integrated, multi-disciplinary foundation, Ecological Urbanism directly links both population and habitat health. This creates a natural opportunity for the design professions to play a more consequential role in shaping the health of urban settlements and, by extension, the regions they center.

Keywords: Urban health. Healthy cities. Ecological urbanism. Air pollution. Urban food production.

\section{Resumo}

Esta edição especial sobre urbanismo ecológico da revista Urbe destaca o esforço de arquitetos, urbanistas e designers em contribuir para cidades mais sustentáveis na América Latina. O objetivo deste estudo é oferecer aos arquitetos e urbanistas evidências científicas sobre como o meio ambiente urbano impacta a saúde. Historicamente, o viver nas cidades primeiro se associou com piores condições de saúde, representando um risco maior para cólera e doenças infecciosas. Depois das medidas sanitárias, viver nas cidades passou a

LF is physiotherapist, specialist, e-mail: laisfajer@gmail.com

NOA is biologist, PhD, e-mail: nilmaraoalves@gmail.com

MSZSC is meteorologist, PhD, e-mail: coelhomicheline@gmail.com

MMV is biologist, PhD, e-mail: verasine@usp.br

PHNS is doctor, academic teacher, e-mail: pepino@usp.br 
ser uma vantagem para a saúde, quando comparado com a vida rural. Atualmente, a América Latina ainda convive com doenças infecciosas características do passado, ao mesmo tempo em que enfrenta um aumento crescente na incidência de doenças crônicas, classe de doenças que prevalecem na cidade e são modificadas pelo ambiente urbano. Com foco multidisciplinar e abordagem fluída entre diferentes escalas de análise, o Urbanismo Ecológico surge como uma solução promissora para proteger simultaneamente a saúde das pessoas e do planeta. Nós esperamos que, depois desta discussão, arquitetos e urbanistas usem a abordagem do Urbanismo Ecológico para abraçar a ideia de proteger a saúde através do exercício de suas profissões.

Palavras-chave: Cidades saudáveis. Urbanismo ecológico. Mobilidade urbana. Poluição do ar. Agricultura urbana.

\section{Introduction}

Changes in cities with the goal of increasing the energy efficiency of buildings, access to low-cost active transportation, and access to green spaces are key steps simultaneously to address climate change and to promote human health (Watts et al., 2015). Eighty percent of the population of Latin America (LA) live in urban areas, and inadequate or unplanned basic infrastructure remains a prevailing condition in many cities of this part of the world. Urban planners, architects and designers are in the position to reverse, or at least to mitigate, most of the unhealthy exposures characteristic of city environments, and the Ecological Urbanism (EU) approach offers a promising framework for addressing these challenges. Distinguished by its integrated, multi-disciplinary foundation, EU directly links population and habitat health, creating a natural opportunity for the design professions to play a more consequential role in shaping the health of urban settlements and, by extension, the regions in which they are centered.

In this paper, we aimed to provide architects and urban planners with empirical evidence about how city environments impact human health. Although there is a growing body of evidence relating city environments to human health, many questions remain unanswered due to the methodological challenges of addressing all of the variables of a complex system such as a city, as well as variability among local city realities. Furthermore, very robust scientific evidence is necessary to change practices linked to economic activities in complex scenarios. In a previous study, we showed that high local knowledge production in the field of air pollution was correlated with better local air quality at the national level (Fajersztajn, et al., 2013). Nawrot and colleagues (2011) showed that air pollution is an important trigger of myocardial infarction, similar in magnitude to other well-accepted risk factors (e.g., physical exertion and alcohol consumption), but the stringency of national air quality standards remains greatly different among countries (Vahlsing \& Smith 2012). Scientists began to associate tobacco with severe health impacts in the early 50s (Doll \& Hill, 1954), but important health-related polices were not implemented in some cities for a long time or were not implemented at all in other cities. Sao Paulo banned smoking in public spaces in 2009, other Brazilian cities banned it in 2014, but Havana has not banned it at all. Thousands of scientists at the IPCC (Intergovernmental Panel on Climate Change) endorsed the scientific evidence for climate change. However, we still do not have a global climate agreement. Without such robust scientific evidence, the international community would likely not be discussing a climate agreement at all (IPCC, 2013).

In this paper, we propose a discussion of the links between the built environment and public health from five thematic standpoints: a) transportation, mobility, and physical activity; b) urban food production; c) urban heat islands; d) thermal comfort and indoor air quality; and e) sanitation and wastewater management. Although we discuss these topics separately, there are overlaps between them. We classified the thematic areas according to Rydin et al. (2012) study because they discussed the role of urban planning in implementing health improvements from the perspective of health, which is our research field.

Despite the progress in the domains listed made over many decades, long before the term EU was coined, the resulting benefits were not experienced by all of the residents of LA cities. Furthermore, city environments are constantly changing (e.g., aging populations, new technologies, and climate change), requiring new and/or flexible approaches to urbanism 
projects. Fluid in scale and with a disciplinary focus, EU has emerged as a promising framework to protect both the population and habitat health.

Nancy Krieger (2014) introduced the social determinants of health in the book Ecological Urbanism, and she showed that the neighborhoods of Boston affect health differently.

The Moving to Opportunity experiment conducted at Harvard University with 4,600 families showed that providing low-income families with assistance to move to better neighborhoods greatly improved the mental and physical health of children and adults (Ludwig et al., 2013; Chetty et al., 2015). If EU could reduce the socioeconomic disparities in a city, it would greatly benefit the health of urban populations in LA. Moreover, there are other forms in which EU can benefit human health. Some of the city-level polices to reduce greenhouse gas (GHG) emissions entail net benefits to human health (Watts et al., 2015).

Usually, different ecological approaches have argued against anthropocentrism because it has resulted in the unsustainable exploitation of nature resources and the related severe impacts on natural ecosystems. However, humans are not only aggressors but also victims, particularly regarding their own health. In Brazil, despite its effectiveness, the body of laws and regulations protecting ecosystems and biodiversity are robust, but the implications for the health of human beings due to changes in city environments are frequently neglected. While a new urban enterprise undergoes a strict environmental impact evaluation before being approved, possible health impacts, such as the adverse effects of noise and local air pollution exposure owing to changes in road use, are barely evaluated (Saldiva, 2010). It is important to emphasize that an ecological approach does not contrast with a human health approach.

The five domains we discuss in this paper are somewhat related to mental health, but considering the increased concern about mental illness in city environments, we will underscore some of these relationships. Although the potential influence of individual characteristics on mental health status is well recognized (WHO, 2014a), less is known about the association between features of the context in which an individual lives and their mental health (Weich et al., 2001). Studies have shown that greater socio-economic disadvantage, a poorer physical and social environment, and higher levels of crime are stressors that can lead to mental illness (Galea et al., 2011). A meta-analysis combined data from 16 countries and concluded that psychiatric disorders are more prevalent in urban areas - a 1.39 times higher risk than in rural settlements (Peen et al., 2010). Mental and neurological disorders account for almost one quarter of the total burden of disease in LA and the Caribbean (PAHO, 2013). Rising levels of violence and mental illness in LA require integrated actions at the government level, as well as in health institutions, society, and other sectors (Harpham, 2009). Urban settlements could shape mental health for the better by reducing social deprivation and violence through the devices discussed in this paper (e.g., community gardens).

In this paper, we first briefly describe the historical links between health and urban planning. Next, we propose a discussion based on the five thematic areas proposed by Rydin et al. (2012): a) transportation, mobility, and physical activity; b) urban food production; c) urban heat islands; d) thermal comfort and indoor air quality; and e) sanitation and wastewater management. At the end of the paper, we present our final considerations, including further directions for research.

\section{Urban planning and health: a historical overview}

Public health and urban planning emerged with the common goal of reducing the harmful health effects of rapid industrialization and urbanization. Both fields were particularly concerned with preventing urban outbreaks of infectious disease (Corburn, 2004).

The first infrastructure improvements to promote better health in the early 19 th century relied on miasma theory, which was the belief that diseases are caused by noxious substances present in bad-smelling air. This theory enhanced public concern with sanitation and hygiene. Engineering-based measures, such as sewers and garbage collection, contributed to containing disease in urban settlements. However, the great sanitary awakening came in the late $19^{\text {th }}$ century, when the association between microorganisms and particular diseases were widely accepted, i.e., germ theory. Public health began to devise specific strategies for controlling and preventing specific diseases, based on laboratory identification of the 
cause of the disease. At the same time, the public responsibility for health began to include not only environmental sanitation, but also individual health. Developing nations followed this trend, but they started the sanitary shift a few decades later, by the middle of the 20th century (Rydin et al., 2012). However, even now, sanitary facilities have not reached the entire urban population of LA, particularly the residents of slums, who are estimated to number 110 million people (FAO, 2014). In Sao Paulo, Brazil, the sanitary awakening started in the late 19th century, marked by the foundation of a company to supply residential water. However, sewage did not receive the same attention. The first law to regulate water pollution in the region was passed in 1940, and until today the sewage treatment rate for the state of Sao Paulo (of which the city of Sao Paulo is the capital) is 53,34\% (Brasil, 2014). Access to health care facilities has played an important role in improving health outcomes in cities (Merzel, 2000), but they are not discussed in this paper.

During the sanitary reform, zoning in countries such as the United States embodied the concept of isolating urban populations from the undesirable externalities of the economy, and it separated the population from areas strictly designated for functions considered unhealthy, e.g., industry (Corburn, 2004). This model probably inspired some LA cities, but their major challenge has been unplanned growth and the continued expansion of slums and substandard housing. Basic urban infrastructure was not implemented at the same pace of the rapid growth of the urban population seen in LA.

Subsequently, urban planning and health aims moved in different directions. The main focus of city planning became enhancing economic outcomes. Public health focused on modifying individual risk factors (e.g., diet, exercise, and smoking), with successful outcomes. However, the health sector largely neglected the social dimensions of disease (Corburn, 2004), restricting the reach of health gains to selected populations.

Over the past few decades, the World Health Organization (WHO) has attempted to increase the overlaps between health and urban planning by two strategies - health in all polices (Ollila, 2011) and the healthy cities movement (Rydin et al., 2012) - but they are not yet robust in LA cities.
Recently, the health community has been concerned about the health impacts of climate change also increasing. In 2009, a series of papers published by The Lancet suggested that actions to reduce GHG emissions often, although not always, entail net benefits for health locally (Haines et al., 2009). This year, the same journal reported that tackling climate change could be the greatest global health opportunity of the 21st century (Dora et al., 2015; Watts et al., 2015). Because lower income populations are more vulnerable to climate change impacts on all scales, not only in comparing nations, but also within the same city, tackling climate change is an opportunity to reduce health inequalities. The EU approach discussed by Mostafavi \& Doherty (2014), in their book that inspired this publication, is a golden opportunity to reinforce the links between public health and urban planning in LA cities, as well as links with the environment.

Building and maintaining cities that shape their residents' health for better are not simple tasks. According to the United Nations, $75.8 \%$ of the LA population live in 198 large cities, and $23 \%$ of urban residents live in slums without access to basic services, such as housing, clean water, and sanitation. Cities are complex systems, and WHO has recommended the use of trial and error in local projects to increase understanding of how best to improve urban health outcomes in specific contexts (Rydin et al., 2012). Hence, communication between city planners and the health sector should be improved and maintained, and this paper makes a contribution to the health discipline. To address this trial and error recommendation, we provide a broad variety of local examples.

In general, chronic non-transmissible diseases prevail in cities and are modified by them. The LA challenge is to face this modern pattern of diseases in highly urbanized regions, along with infectious diseases and widespread health inequality issues. The collaborative work between the health sector and urban planners might result in a considerable health gain for the region, particularly if planners focus on strategies to reduce the health inequalities within cities.

Historically, controlling the environment through technology (engineering-based measures) was the main concept driving the cooperation between the public health and urban planning fields, first through sanitary-based measures and then using a more sustainable design. Currently, architects and urban 
planners seek alternative design approaches to address the whole infrastructure of cities in the EU. Some high income cities follow each step of this process. LA cities follow more flexible pathways because some of these cities are already implementing an EU approach, but they continue to struggle with poor sewage drainage and low-efficiency buildings.

\section{Transportation, mobility, and physical activity}

According to the WHO, transportation is one of the social determinants of health. However, its health aspects are not routinely addressed during the formulation and planning of urban transport polices in many LA cities (WHO, 2011).

The flow of goods and people within and through cities can negatively affect the health of people, the environment, and the economy. Therefore, there is an urgent need to improve transport in cities to address time and air pollutant emissions.

Currently, the urban environment in LA is frequently characterized by industrialization and environmental deterioration, as well as crowded cities surrounded by peri-urban poverty, traffic congestion, and few or low quality (comfort and time spending) public transportation options. The prevalent mode of transportation in cities is private cars. Moreover, having a car is synonymous with mobility, comfort, and status (Newman \& Kenworthy, 1999). However, this mode of transportation results in serious health and environmental problems. Cars restrict physical exertion, contribute to isolation from social interaction and stress, and result in loss of hours from work and leisure due to time spent in traffic. Furthermore, cars contribute to air and noise pollution, negatively influencing health (Rissel, 2009). Additionally, car accidents kill thousands of people every year (Fletcher \& McMichael, 1996 apud McMichael, 1996).

Hundreds of scientific studies have shown how transportation options can improve health status, prevent sedentarism-related diseases and mitigate harmful environmental impacts (e.g., greenhouse gases emission and urban air pollution). Environment-friendly and healthy alternatives include walking, cycling, and the use of public transportation. However, these alternatives must be safe, comfortable, accessible, inexpensive, convenient, efficient, and integrated to cover the whole city to stimulate their use, thus constituting a challenge for urban planners.
In Europe, strategies to create cycle networks and integration between cycling and public transportation have been successful, stimulating the use of active transport with significant environmental and health gains (Pucher \& Buehler, 2008, 2007).

A recent systematic review of the health impacts of active transportation, conducted by Mueller et al. (2015), emphasized that active transport provides health benefits despite the risks of traffic accidents and exposure to air pollution, which are outweighed by the positive outcomes. Active forms of transportation are linked to increased physical activity and social interaction. Physical activity can improve the health status of an individual and can reduce the risk of developing several diseases, e.g., type 2 diabetes, hypertension, and obesity. Nevertheless, more than $30 \%$ of adults worldwide perform insufficient physical activity. Moreover, insufficient physical activity, together with a high-energy diet, is one of the causes of obesity. Active modes of travel can reduce the number of cars on the streets, thus benefiting the health by reducing air pollution.

Unlike in Europe and North America, fewer cities in LA have introduced active transportation initiatives. The recent review conducted by Moeller and colleagues did not find studies conducted in LA, but the authors excluded studies in Spanish and Portuguese Language. A search in the PubMed database (using the keywords "active transportation" and "physical activity") yielded 736 results but only four when the keyword "Latin America" was added. Moreover, only one (Becerra et al., 2013) study was in fact on the topic. According to Becerra and colleagues, the appeal for active transportation in LA is based on reducing traffic congestion and not on the environmental and health benefits of these strategies (Becerra et al., 2013). Ideally, both the health and environmental sectors should participate in the decision-making process, and urban planners should be aware of the impacts of a built environment and transportation modes on health.

In contrast, the Web sites of South American cities depict initiatives in Sao Paulo, Rio de Janeiro, Curitiba, Bogotá, Buenos Aires, and Santiago. The World Bank has also published reports on the successful implementation of BRT (bus-based rapid transit) systems in different countries (e.g., Ecuador, Mexico). Initiatives that stimulate active transport also include the construction of exclusive bike lanes 
and the closure of streets to motorized traffic during the weekends and on holidays for cycling, running, and walking. Evaluation of the health benefits of these initiatives has been rare, and the methods to estimate or predict their health impacts are not precise. Laverty et al. (2015) examined the correlations among socio-demographic status, the use of active travel, and specific health outcomes (adiposity, diabetes, blood pressure) in adults (mean age: 58 years old) from six middle-income countries: Mexico, China, India, South Africa, Russia, and Ghana. They found that people who use more active modes of transport presented a reduced risk of being overweight and lower systolic blood pressure and BMI (body mass index). Saunders et al. (2013) noted that active travel could have positive effects on health outcomes but not specifically on obesity.

Thus, active transportation not only reduces urban traffic, air pollution, and climate-associated changes, but it also improves the health status of people. The benefits rely on healthy increases in physical activity and social interaction, and on reducing the levels of air-pollutant exposure in urban areas, which constitutes a major environmental risk factor for cardiovascular disease and lung cancer. The only way to reduce air pollution exposure is to reduce ambient levels, which requires reducing the emission of pollutants. According to the WHO (2014b), in 2012, there were 58,000 premature deaths in LA due to air pollution exposure.

Vehicle fleets contribute the most to GHG emissions and therefore to climate change, as well as increased mortality owing to extreme temperatures. The impact of temperature on health will be discussed in the "Urban heat islands" section of this paper.

Active transport integrated into an efficient public transportation system is an alternative to improve human health, reduce environmental pollution, and mitigate climate change. The challenge that urban planners and policy makers face today in developing counties is how to implement these changes in previously built urban environments designed to favor the private car mode of transport and to attract users.

\section{Urban food production}

Despite the widespread notion of food production as an exclusively rural activity, the growing of plants and raising of animals within and around cities (FAO,
2014) are not new occurrences. Food insecurity due to poverty (Zezza \& Tasciotti, 2010; Wolch et al., 2014), war (Milburn \& Vail, 2010; Rydin et al., 2012), and natural disasters (Hara et al., 2013) has assured the occurrence of the activity in past decades. At present, UPA (Urban and Peri-urban Agriculture) is also reemerging in the more sustainable cities of developed nations (Middle et al., 2014; Hara et al., 2013; Rydin et al., 2012).

It is not possible to project that UPA will replace traditional forms of feeding in highly populated cities, but the potential benefits for ecology and human health cannot be ignored. The WHO appealed to cities and their governments to incorporate food policies into urban plans (Rydin et al., 2012).

UPA is widespread in LA. In Rosario, Argentina, 1.35 million inhabitants have 800 community gardens producing vegetables for 40,000 people (FAO, 2014). In Mexico City, nearly 23 thousand ha of land are dedicated to crop production, and in Cuba agriculture is practiced by 40 thousand urban workers on an estimated area of 33,500 ha (FAO, 2014).

The benefits of urban food production range from improvements in health and social outcomes to environmental and economic benefits. UPA is good for health because it improves human nutrition. Compared with other urban dwellers, urban producer families have more diverse diets and consume more vegetables and fruits (FAO, 2014). Low ingestion of vegetables and fruits is a major risk factor for the global burden of disease (Lim et al., 2012). In LA and the Caribbean, low intake of whole grains and other nutrition-related risks are also among the top ten major risk factors for disease. Better nutrition benefits cardiovascular health (Hu et al., 2001) and helps to combat other non-communicable diseases, such as obesity (Gatto et al., 2015) and diabetes (Tohill et al., 2004). UPA also creates opportunities for physical activity, reinforcing the described health gains (Rydin et al., 2012). Furthermore, engaging in urban food production potentially enhances emotional health through stress reduction and socialization. Along with improving access to quality food, UPA has proved to be an important response to anticipated food shortages due to natural disasters, droughts, and increases in food prices, among other situations (Hara et al., 2013; Rydin et al., 2012; Angnotti, 2015).

The services to the ecosystem from agriculture include the regulation of water and climate systems, 
maintenance of soil fertility, and the regulation of pollination, among others (Swinton et al., 2007). When food is locally produced, there is a reduction in transportation demand, resulting in energy savings and a decrease in the emissions of air pollutants (Angnotti, 2015; Hara et al., 2013), all of which are ecological gains. Other potential gains include reduction in solid waste exporting due to composting projects (FAO, 2014) and better management of rainwater through wider urban green coverage, which also allows for groundwater restoration (Angnotti, 2015).

UPA contributes to economic growth through employment and other forms of income generation because families engaged in UPA reduce their spending on food and earn additional income from sales (FAO, 2014). Revitalization of low-income communities (Angnotti, 2015) and the raising of the value of local housing due to the amelioration of landscape aesthetics (Rydin et al., 2012) might emerge as indirect social and economic gains. Security is enhanced by greater civic involvement and the presence of more people outside in yards and gardens (Rydin et al., 2012), which also promote social cohesion (FAO, 2014).

The agro-ecological approach enhances environmental and nutritional gains (Baranski et al., 2014) and perfectly suits EU values because both concepts share integrative views of environmental sustainability. Furthermore, the agro-ecological approach might be cost-effective in specific settings. In Havana, producing 1 million tons of vegetables via organic agriculture is US\$39.5 million less expensive than conventional agriculture (FAO, 2014).

Despite its particular challenges, the city is an appropriate venue for integrating food production with other ecosystem services (FAO, 2014). Even in densely populated areas, food can be produced in containers on rooftops and balconies, in parks and elsewhere. It is important to note that food production in the city is possible, but replacing the current forms of food supply to feed cities is not yet possible, and it is not currently a goal at all. UPA should ideally occur alongside the current forms of food supply, and EU might be an appropriate approach for UPA and other forms of food supply to cities coexisting.

The dominant form of urban food production in LA is backyard family horticulture and school gardens, but the region also has other forms of community and commercial gardens. UPA production includes the farming of vegetables, fruits, and cereals, the raising of small animals for eggs and meat, and the growing of flowers. All age groups and walks of life are engaged in these activities, but most of them come from low-income households. Women are the more prevalent gender, particularly in the Caribbean, Bolivia, Colombia, Ecuador, Honduras, and Nicaragua (FAO, 2014). In El Alto, Bolivia, a gardening project taught more than one thousand families production techniques adapted to the city's agro-climatic conditions. The result is that, in one year, a typical family produces nearly 1 ton of tomatoes, saves US $\$ 60$ a month on food purchases, and earns US $\$ 15$ from the sale of surpluses (FAO, 2014).

UPA is under increasing pressure from urbanization itself. A major issue is the lack of space, resulting in the high cost of land and competitive use. In the peri-urban area of Rosario, Argentina, soybeans for export have displaced other traditional produce for the domestic market, such as wheat, sunflowers, milk, and fruit. In Mexico City and Lima, slums and industrial activity have been impairing water quality and availability for agriculture use (FAO, 2014). Technical issues can be overcome, but most cities must still face the lack of quality seed, the poor quality of soils, and the unreliability of water supplies (FAO, 2014). There is also the need to overcome UPA-related trade issues, including the high cost of inputs and the unavailability of credit to buy tools and processing equipment; very limited access to markets is also a major issue (FAO, 2014; Angnotti, 2015). Moreover, the overuse of agrochemicals exposes some small farmers to health risks and impairs environmental quality, polluting water supplies and other natural resources (FAO, 2014).

Finally, we draw attention to the role of contaminated soil in urban areas, which often contains dangerous levels of heavy metals (Cheng et al., 2011; Ferri et al., 2015). Heavy metals are present in the soil of many urban vegetable gardens in the United States and Europe (Clark et al., 2008; Cheng et al., 2011; Burt et al., 2014; Ferri, et al., 2015), prompting questions about the potential health consequences of UPA in contaminated areas.

Lead and other heavy metals have been strongly linked to severe cognitive, motor and behavioral disorders in children (Grandjean \& Landrigan, 2006). Researchers agree that the exposure routes for humans occur through accidental ingestion of the soil and inhaling of contaminated dust (Kessler, 2013), posing 
risks to farmers, particularly children. There is less consensus about the health effects of the consumption of crops grown in contaminated soil (Warming et al., 2015; Ferri et al., 2015; Augustsson et al., 2015), probably due to the general lack of studies, particularly in LA. The broad range of variables involved - soil constitution, type of pollutant, type of crop - has impaired comparisons between studies. Hence, the most prudent attitude is to follow the specific management practices for urban gardeners (Kessler, 2013), which can help to prevent these harmful exposures. Some of these recommendations are closely related to urban planners' activities, such as building gardens away from existing roads.

More successful UPA in LA cities has received technical support from international organizations and/or NGOs. Political will has also played a role. Cities where local UPA was successful also inspired national policies, spreading UPA across the country, as occurred in Nicaragua and Honduras (FAO, 2014).

Enhancing UPA requires support from all levels of government because it should be integrated with activities from different levels of governance, such as solid waste management, water supply, and education. In LA, 12 countries have implemented national policies promoting UPA (FAO, 2014).

Many LA cities use composting for urban organic waste fertilizer (FAO, 2014). The region also has experience in better managing of water, storing rainwater, reusing resources, and using technologies that conserve water. In El Alto, new technologies have reduced by $80 \%$ the need for water by crops (FAO, 2014). There has also been successful experience with converting pig manure into biogas and selling the energy to urban residents (FAO, 2014). In general, all schools, parks, and community facilities are candidates for composting projects and for growing food (Angnotti, 2015).

Zoning urban areas for agriculture can protect against competition with other land uses and can facilitate the recognition of UPA as an economic activity. However, zoning usually neglects UPA (Rydin et al., 2012); only three nations in LA have explicitly included it in their occupation planning (FAO, 2014). Furthermore, protecting sustainable agriculture by small-scale farmers in peri-urban agriculture by law could safeguard water reservoirs (FAO, 2014).

Before choosing an area for UPA, it is recommended that the local conditions (soil, light incidence, water supply, etc.) be evaluated. In the absence of contaminant tests (the gold standard), the local history of urbanization and industrialization has indirectly addressed the potential contamination of the soil. In cases of previous industrial activities, gas stations, and laundry services, it is prudent to consider the soil contaminated. Remediation is frequently possible, but the unavailability of specialized services at some sites and the high costs might be impediments. Building raised beds and importing healthy soil are alternatives (Rydin et al., 2012; Angnotti, 2015; Kessler, 2013). Kessler (2013) summarized the best management practices for urban gardeners, including agricultural practices (e.g., covering existing soil and walkways with mulch) and good habits (e.g., wearing gloves).

Financial-related mechanisms, such as heavily taxing vacant land and providing credits for urban farming, can play key roles in overcoming the high cost of land (Angnotti, 2015).

Architects and designers have already developed solutions to cope with the lack of space for activity; vertical farms, including rooftop crops, are an example (Torreggiani et al., 2012).

Specific polices can address technical issues with UPA, such as lack of quality seed, poor quality of soils, and the unreliability of water supplies. The same is true for trade-related issues, such as the high cost of inputs, the unavailability of credit for equipment, and lack of access to markets. Experiences in LA have shown that trading production with schools and hospitals and promoting technologies that add value to UPA production enhance the activity. In Antigua and Barbuda, fruit drinks and sun-dried hot peppers from backyard gardens are improving the financial gains of gardeners (FAO, 2014).

Occupational health risks owing to the overuse of agrochemicals can be prevented by the agro-ecological approach, which is also aligned with ecological values. In some countries, the use of synthetic pesticides and fertilizers is forbidden by law.

Finally, urban planners and designers can incorporate UPA concepts while planning new buildings and cities. In China, some buildings have been planned with level rooftop surfaces that can be used for farming. The arrangement improves the solar angle for natural lighting within apartment buildings, as well as natural cross-ventilation (Rydin et al., 2012). 


\section{Urban heat island}

The accelerated urbanization rate is changing the landscape and soil coverage. Buildings, roads, and other infrastructure have replaced land and vegetation, resulting in elevated temperatures in urban areas, compared to their outlying rural surroundings, which is a phenomenon known as urban heat islands (Berdahl \& Bretz, 1997; Sobral, 2005).

The magnitude of surface Urban Heat Islands (UHIs) varies by the season, due to changes in the sun's intensity, ground cover, and weather. Atmospheric UHIs are often weak during the late morning and throughout the day and become more pronounced after sunset due to the slow release of heat from the urban infrastructure. The timing of this peak depends on the properties of urban and rural surfaces, the season, and prevailing weather conditions (Akbari, 2005). Increased daytime surface temperatures, reduced nighttime cooling, and higher air pollution levels associated with UHIs can affect human health by contributing to general discomfort, respiratory difficulties, heat cramps and exhaustion, non-fatal heat stroke, and heat-related mortality. UHI can also exacerbate the impact of heat waves, which are periods of abnormal heat. Sensitive people, children, the elderly, and those with chronic diseases are at major risk. The Centers for Disease Control and Prevention estimated that, from 1979 to 1999, excessive heat exposure contributed to more than 8,000 premature deaths in the United States (CDC, 2004).

Urban pollution contributes to complex atmospheric processes (Akbari, 2005; EPA, 2006); hence, the emission of pollutant gases must be considered when analyzing the meteorological variables of large cities (Coelho et al., 2010).

In Sao Paulo, the thermal gradient between the outskirts and the central zone can reach $10^{\circ} \mathrm{C}$. The reduction of green coverage, the increased use of fossil fuels, and the construction of high buildings that act as ventilation barriers can explain UHIs (Sobral, 2005). In addition, modifications of the urban thermal profile affect sensible heat, latent heat and momentum fluxes, surface convergence, optical properties of the atmosphere, boundary-layer height, and other boundary-layer features. Such changes impact pollution dispersion, thunderstorm initiation, and many other physical and chemical processes in the urban environment (Khan \& Simpson, 2001).
Despite the broad variety of meteorological systems that affect Sao Paulo, the city presents two well-defined seasons: Spring-Summer (hot and wet) and Fall-Winter (cold and dry) (CDC, 2004), but extreme weather events intensified by climate change are becoming more frequent (Bornstein \& Lin, 2000). In winter, pollutant concentrations can be critical because of the low availability of solar energy, limiting the development of the planetary boundary layer. Hence, pollution dispersion is heavily dependent on the strength of the heat island circulation (Bornstein \& Lin, 2000). The health consequences are increasing hospital admissions due to cardiorespiratory diseases (Coelho et al., 2010; Braga et al., 2002; Saldiva et al., 1992), and sometimes death (WHO, 2004). UHIs also increase ground-level formation of ozone, which is a pollutant related to acute asthma crises (Andrade et al., 2004). Nitrogen and volatile organic compounds, which are released from fossil fuel combustion, react in the presence of sunlight, forming ozone, particularly during the high temperature periods of late spring and early autumn (Hsieh et al., 1999; Andrade et al., 2004). Further, the temperature gradient between central (hot) and peripheral areas (less hot) of the city from UHIs increase heavy rain events in the central part of the city (Freitas et al., 2007). Urban effects can be particularly important for explaining the daily rainfall extremes in the summer (Silva Dias et al., 2013), leading to floods and associated health problems (leptospirosis infections).

Thermal pollution can aggravate respiratory and cardiovascular diseases (WHO, 2004; Guo et al., 2014; Laschewski \& Jendritzky, 2002), and it is associated with discomfort and physiological stress. The thermal comfort neutrality range falls between $17^{\circ} \mathrm{C}$ and $31^{\circ} \mathrm{C}$. Above that temperature, hypotension, hyperthermia, tachycardia, heart failure, poor appetite, dehydration, fatigue, irritability, decreased learning ability, impaired memory, and depression may occur. An increase in air temperature also impacts flora and fauna, influencing the distribution of vector-borne diseases, such as dengue fever (Coelho \& Massad, 2012; Laschewski \& Jendritzky, 2002).

Moreover, changes in meteorological parameters in large cities due to urbanization and global warming have affected weather in these places. As a result, heat waves, dry weather, and rain are very likely to increase in both frequency and intensity. In urban regions, these future heat waves will be exacerbated by the UHI effect 
and will have the potential to influence negatively the health and welfare of residents. In Shanghai, China, a study showed that UHIs are directly responsible for adverse health effects due to exposure to extreme thermal conditions (Tan et al., 2010). Socioeconomic factors modulate the health burden of temperature extremes (Urban et al., 2014; Burkart et al., 2011). Temperature and mortality are usually associated. In England and Wales, a study analyzed 10 areas during the summer from 1993 to 2006, and heat was associated with increased mortality in nearly all causes of death in the elderly (Gasparrini et al., 2012).

Weather event extremes present a significant health risk, and the hazard is likely to escalate with the increased future temperatures presently predicted by climate change models. The impact of heatwaves is often stronger in densely populated cities and where the climate is involuntarily modified to produce an UHI effect.

Humans have mechanisms for managing additional heat and cold, but overcoming this vital threshold can lead to serious health conditions. A recent study published in The Lancet with 384 locations in 13 counties revealed that uncomfortable ambient temperature is responsible for considerable increases in mortality, with significant differences between countries. According to the results, the temperature is responsible for increasing a considerable proportion of deaths to $7.71 \%$ (95\% CI 7.43-7.91). Nevertheless, there are significant inter-country variations in attributable risk (for both hot and cold), with the uppermost attributable risk in Italy, China, and Japan and the lowermost estimates in Thailand, Brazil, and Sweden (Gasparrini et al., 2015).

Health impacts and vulnerability due to extreme weather events require systematic approaches and integrated policy and planning responses from a range of government agencies. Unfortunately, effective mitigation actions are almost non-existent in Brazil. According to Marengo et al. (2009), by 2100, the average temperature may have risen between $2{ }^{\circ} \mathrm{C}$ and $4{ }^{\circ} \mathrm{C}$ in Brazil, compared with the average temperatures recorded between 1961 and 1990. Thermal discomfort conditions will affect thousands of people. There will likely be an increase in the number and severity of cases of heart disease, asthma and infections. At a higher level of severity, individuals who use medication chronically to control respiratory and heart diseases will require higher doses to control their illnesses to cope with environmental changes. Increased susceptibility to pollutants and climatic factors is dependent on individual, environmental and socioeconomic factors and on housing conditions (Souza \& Macedo, 2010).

In contrast, developed countries have implemented significant mitigation policies in urban planning, with a focus on sustainability and energy but that indirectly have co-benefits to health. For example, Green Infrastructure (GI) has contributed to the mitigation of UHIs. In the context of climate change, with the expected increase in temperature, the dryness and intensity of heat waves, and storms and floods, green areas assume even greater importance because they can create a cooling effect that extends to surrounding areas.

The project of the Urbanism, Climate Adaptation and Health Cluster, funded by the CSIRO Climate Adaptation Flagship, focuses on improving understanding of the interactions between climate and health in urban areas in Australia, using green infrastructure (GI) to address high temperatures and dry humidity (CRC, 2012).

A European commission has produced guides to assist authorities and stakeholders in investing in Green Infrastructure (GI) through the Cohesion Fund for 2014-2020. The first is a guide to "multi-benefit cohesion policy investments in nature and green infrastructure" (European Commission, 2015).

Seven federal agencies have united to support the Green Infrastructure Collaborative in the United States of America. These agencies signed a Federal Letter of Support committing to specific actions to promote green infrastructure. The cooperating agencies are the EPA, the Department of Housing and Urban Development, the Department of Transportation, the Department of Agriculture, the Department of the Interior, the Department of Defense, and the Department of Energy (EPA, 2014).

Implementation of UHI mitigation strategies, such as increased vegetative cover and higher-albedo surface materials, was suggested by studies performed in New Jersey addressing issues such as economic efficiency and the reduction of energy consumption and costs at the sites (Solecki et al., 2005). Urban food production, previously discussed in this paper, might be an option for vegetative cover. 
Finally, interventions can be implemented at various levels: urban planning, with the implementation of climate controlling factors, such as afforestation, squares, streets, policies to decrease emissions from pollutants, etc.; and housing, with improvements in the constructive conditions that favor thermal insulation to protect residents (more information in the "Thermal comfort and indoor air quality" section).

A third level of intervention is education: educational campaigns and awareness of the adverse effects of weather and orientation of attitudes could facilitate protection against cold/heat or pollution (Sobral, 2005; CDC, 2004).

\section{Thermal comfort and indoor air quality}

Urban planners, architects, and designers can help to assure better indoor quality and thermal comfort for urban inhabitants at home, work, school or other facilities. The major challenge will be how to improve indoor environments for the 110 million slum dwellers in LA (2010) (FAO, 2014).

Indoor air pollution is among the top risk factors for chronic diseases in LA (Lim et al., 2012), and it was responsible for $7 \%$ of the premature deaths in the region (WHO, 2014b) in 2010. Indoor air quality is modulated by air exchange, outdoor pollutant levels, and the production of indoor pollutants (Rydin et al., 2012). Architects are in the position to improve air exchange and consequently indoor air quality.

The burning of solid fuels for cooking and heating is the most studied source of indoor air pollution. The impacts on health include increased risks of pneumonia in children ( $<5$ years old) and of chronic obstructive pulmonary disease, cardiovascular disease, cataracts, and lung cancer in adults (Smith et al., 2013). Women and small children are the most vulnerable because they spend the most time in or near the kitchen. The lack of access to clean energy sources can also result in other health risks, such as burns, injuries, intoxication, and violence against women while they collect fuel (Dora et al., 2015).

In Brazil, the highest percentage of a population in a metropolitan region without a stove at home was $1.76 \%$ in Fortaleza (IBGE, 2011). However, this percentage could be significantly higher in the less-developed countries of LA (Laborde et al., 2015). More efficient biomass stoves (ideally attaining nearly complete combustion) have been a successful solution. In Guatemala, child pneumonia decreased by half in houses that successfully $(90 \%$ reduction in the levels of indoor air pollutants) installed wood stoves with chimneys (Smith et al., 2011). Additionally, improved cooking stoves reduce GHG emissions, both benefiting public health and mitigating climate change (Wilkinson et al., 2009). Affordable household electricity would also result in better indoor air quality because the use of gas or electricity to cook creates little or no pollution in the kitchen (Smith et al., 2013). However, improving household ventilation is an important mitigation strategy, and architects and designers must be aware of it.

Similarly, improved insulation, efficiency of heating and the use of other building materials that reduce heat losses through the walls, windows, and roof are among the successful strategies to reduce energy use (Rydin et al., 2012).

Warmth and energy efficiency interventions can improve general health, particularly in people with previous chronic respiratory diseases (Thomson et al., 2013). Furthermore, thermal comfort strategies are likely to improve cardiovascular health because low indoor temperature is associated with a higher risk of high blood pressure (Shiue \& Shiue, 2014)

Indoor tobacco smoke is also a recognized source of indoor air pollutants (Laumbach \& Kipen, 2014). Restricting smoking indoors is an effective police for reducing exposure (Sebrié et al., 2008), but it is probably beyond the abilities of urban planners. However, improving ventilation can also help mitigate exposure to indoor tobacco smoke.

Asbestos is a carcinogenic substance (IARC, 2009) related to a wide variety of lung diseases (O'Reilly et al., 2007), including asbestosis, a disease caused by the inhalation of asbestos (Bledsoe et al., 2014). Due to its insulating, fire-resisting and sound-absorbing properties, asbestos was usually mixed with cement for building construction materials, particularly roofing products (Haynes, 2010). Asbestos is virtually banned in most developed countries (Laborde et al., 2015). In LA, Argentina, Chile, Uruguay and Honduras have also banned asbestos (Laborde et al., 2015). In the other countries, if possible, architects and designers should avoid using building materials with asbestos and other noxious compounds (e.g., formaldehyde) in their composition to improve indoor air quality (Wang \& Zhang, 2009). 


\section{Sanitation and wastewater management}

Safe drinking water access and sanitation are basic human rights (UN, 2010). There is widespread understanding that the lack of access to safe drinking water, sanitation, and hygiene affects human health (WHO/UNICEF, 2014), particularly causing diarrheal outbreaks. Malnutrition, vector-born disease (e.g., dengue fever), neglected tropical diseases (e.g., schistosomiasis), and non-communicable disease risks related to chemical contaminants are recognized health outcomes (Freeman et al., 2013; Bartram et al., 2005). Poor people are at greater risk because their access to improved water sources and sanitation is restricted (Dora et al., 2015)

In LA and the Caribbean, the access to safe drinking water reached $94 \%$ of the population in 2012. The lowest levels of coverage were found in the Dominican Republic, Ecuador, Haiti, Nicaragua and Peru, ranging from $76 \%$ to $90 \%$ (WHO/UNICEF, 2014).

The scenario is worse for improved sanitation facilities. In 2012, 110 million people in the region still lacked access to sanitation, despite improvements in previous years (WHO/UNICEF, 2014). One explanation is that investment in infrastructure to supply water tends to be seen as a priority by politicians and citizens, whereas the disposal of human excreta is comparatively neglected (Rydin et al., 2012).

According to the WHO/UNIFEC Joint Monitoring Program for Water Supply and Sanitation, an improved drinking-water source is protected from outside contamination, in particular from contamination with fecal matter, and should include: piped water into dwellings; piped water to yards/plots; public taps or standpipes; tubewells or boreholes; protected dug wells; protected springs; and rainwater (WHO/UNICEF /JMP). An improved sanitation facility is one that hygienically separates human excreta from human contact: flush toilets, piped sewer systems, septic tanks, flushing/pouring to pit latrines, ventilated improved pit latrines, pit latrines with slabs and composting toilets. Flushing/pouring to outside, pit latrines without slabs, buckets, hanging toilets or hanging latrine, and a lack of facilities or bushes or fields are classified as unimproved sanitation facilities (WHO/UNICEF, 2015). However, many unimproved systems might be misclassified, (Rydin et al., 2012) and improved drinking water sources might still contain substantial bacterial and chemical contamination (Dora et al., 2015).

In addition, climate change is expected to increase the risk of water shortages in urban areas (Dora et al., 2015), threatening the achievements of water and sanitation facilities. In 2015, the water sources of the city of Sao Paulo decreased drastically, impairing the water supply. At the beginning of the year, the city also faced a severe dengue fever epidemic. Inadequate rainwater collection and water storage are possible causes of the increase in dengue fever cases in 2015.

Ideally, all households should have a potable water supply for internal bathrooms and kitchens, a flushing toilet, and storm drainage to prevent flooding, but in many cities, this set of standards can only be achieved in the wealthiest neighborhoods. Informal settlements are of particular concern (Rydin et al., 2012). In Rio de Janeiro, Brazil, people living in informal settlements (1.39 million people) have less access to adequate water and sanitation, compared with the other residents of the city (Snyder et al., 2014). Urban planning regarding sanitation must focus on reducing unequal access. A major challenge is defining who will pay for it. Usually, city authorities see on-site toilet facilities as the responsibility of individuals. Poor houses in informal settlements are unlikely to have financial capital invested in such facilities, particularly those living in rental properties (Rydin et al., 2012).

A recent report described a step-by-step approach to the complex circumstances surrounding the need to provide sanitation to urban areas, particularly to densely populated areas and to the less affluent sectors of society. It considered financial issues, as well as other dimensions, institutional, environmental, technical and social (Galli et al., 2014).

Considering all of the dimensions, increasing the effectiveness of sanitation measures results in health protection for those that received these facilities. However, if city planners also consider the concepts of ecological urbanism, the environment would also be protected. In addition, the ecological urbanism approach is a tool for integrating the planning of green areas and sanitation, both of which are essential for the environment and human health. The "Urban heat islands" and "Urban food and agriculture" sections discussed some of the wide variety of benefits to green spaces. 


\section{Final considerations}

Ecological and human health gains in city environments are not at odds. Distinguished by its integrated and multi-disciplinary foundation, EU is an opportunity to promote population and habitat health and to reduce health inequalities in LA, a part of the world where $80 \%$ of population lives in cities, $23 \%$ of it in slums.

The empirical evidence discussed in this paper shows that urbanism-related measures can shape human health for better or worse. Experiences from developed (more abundant) and LA cities can inspire the use of trial and error in local projects in LA to increase understanding of how best to improve urban population and habitat health, applying an EU approach in specific urban contexts.

Similar to initiatives that have proposed indicators linking health and sustainability for the post-2015 development agenda, a next step to enhance the links between EU and population health could be the proposal of health indicators that shape human health for better city environments.

\section{References}

Akbari, H. (2005). Energy saving potentials and air quality benefits of urban heat island mitigation. Berkeley: Lawrence Berkeley National Laboratory. Retrieved in 08 June 2015, from http://www.osti.gov/scitech/servlets/purl/860475

Andrade, M. F., Ynoue, R. Y., Harley, R., \& Miguel, A. H. (2004). Air-quality model simulating photochemical formation of pollutants: the São Paulo Metropolitan Area, Brazil. International Journal of Environment and Pollution, 22(4), 460-475. http://dx.doi.org/10.1504/IJEP.2004.005681

Angnotti, T. (2015). Urban agriculture: long-term strategy or impossible dream? Lessons from Prospect Farm in Brooklyn, New York. Public Health, 129(4), 336-341.

Augustsson, A. L. M., Uddh-Söderberg, T. E., Hogmalm, K. J., \& Filipsson, M. E. M. (2015). Metal uptake by home grown vegetables: the relativeimportancein human health risk assessments at contaminated sites. Environmental Research, 138, 181-190. http://dx.doi.org/10.1016/j. envres.2015.01.020. PMid:25723126.

Baranski, M., Srednicka-Tober, D., Volakakis, N., Seal, C., Sanderson, R., Stewart, G. B., Benbrook, C., Biavati, B., Markellou,
E., Giotis, C., Gromadzka-Ostrowska, J., Rembiałkowska, E., Skwarło-Sońta, K., Tahvonen, R., Janovská, D., Niggli, U., Nicot, P., \& Leifert, C. (2014). Higher antioxidant and lower cadmium concentrations and lower incidence of pesticide residues in organically grown crops: a systematic literature review and meta-analyses. British Journal of Nutrition, 112(5), 794-811. http://dx.doi.org/10.1017/ S0007114514001366. PMid:24968103.

Bartram, J., Lewis, K., Lenton, R., \& Wright, A. (2005). Focusing on improved water and sanitation for health. Lancet, 365(9461), 810-812. http://dx.doi.org/10.1016/ S0140-6736(05)71007-2. PMid:15733725.

Becerra, J. M., Reis, R. S., Frank, L. D., Ramirez-Marrero, F. A., Welle, B., Cordero, E. A., Paz, F. M., Crespo, C., Dujon, V., Jacoby, E., Dill, J., Weigand, L., \& Padin, C. M. (2013). Transport and health: a look at three Latin American cities. Cadernos de Saude Publica, 29(4), 654-666. http://dx.doi. org/10.1590/S0102-311X2013000800004. PMid:23568296.

Berdahl, P., \& Bretz, S. (1997). Preliminary survey of the solar reflectance of cool roofing materials. Energy and Building, 25(2), 149-158. http://dx.doi.org/10.1016/ S0378-7788(96)01004-3.

Bledsoe, J. R., Christiani, D. C., \& Kradin, R. L. (2014). Smoking-associated fibrosis and pulmonary asbestosis. International Journal of Chronic Obstructive Pulmonary Disease, 10(1), 31-37. http://dx.doi.org/10.2147/COPD. S74643. PMid:25565798.

Bornstein, R., \& Lin, Q. (2000). Urban heat islands and summertime convective thunderstorms in Atlanta: three case studies. Atmospheric Environment, 34(3), 507-516. http://dx.doi.org/10.1016/S1352-2310(99)00374-X.

Braga, A. L. F., Zanobetti, A., \& Schwartz, J. (2002). The effect of weather on respiratory and cardiovascular deaths in 12 U.S. cities. Environmental Health Perspectives, 110(9), 859-863. http://dx.doi.org/10.1289/ehp.02110859. PMid:12204818.

Brasil. Ministério das Cidades. Secretaria Nacional de Saneamento Ambiental - SNSA. (2014). Sistema Nacional de Informações sobre Saneamento: diagnóstico dos serviços de água e esgotos: 2013. Brasília: SNSA/MCIDADES. 181 p.

Burkart, K., Schneider, A., Breitner, S., Khan, M. H., Krämer, A., \& Endlicher, W. (2011). The effect of atmospheric thermal conditions and urban thermal pollution on all-cause and cardiovascularmortality in Bangladesh. Environmental Pollution, 159(8-9), 2035-2043. http://dx.doi.org/10.1016/j. envpol.2011.02.005. PMid:21377776. 
Burt, R., Hernandez, L., Shaw, R., Tunstead, R., Ferguson, R., \& Peaslee, S. (2014). Trace element concentration and speciation in selected urban soils in New York City. Environmental Monitoring and Assessment, 186(1), 195215. http://dx.doi.org/10.1007/s10661-013-3366-1. PMid:23943242.

Central of Disease Control - CDC. (2004). Extreme heat: a prevention guide to promote your personal health and safety. Atlanta: CDC. Retrieved in 08 June 2015, from http:// www.bt.cdc.gov/disasters/extremeheat/heat_guide.asp

Cheng, Z., Lee, L., Dayan, S., Grinshtein, M., \& Shaw, R. (2011). Speciation of heavy metals in garden soils: evidences from selective and sequential chemical leaching. Soils Sediments, 11(4), 628-638. http://dx.doi.org/10.1007/ s11368-011-0351-6.

Chetty, R., Hendren, N., \& Katz, L. F. (2015). The effects of exposure to better neighborhoods on children: new evidence from the moving to opportunity experiment. American Economic Review. Retrieved in 08 June 2015, from http://scholar.harvard.edu/hendren/publications/ effects-Exposure-Better-Neighborhoods-Children-NewEvidence-Moving-Opportunity.

Clark, H. F., Hausladen, D. M., \& Brabander, D. J. (2008). Urban gardens: Lead exposure, recontamination mechanisms, and implications for remediation design. Environmental Research, 107(3), 312-319. http://dx.doi.org/10.1016/j. envres.2008.03.003. PMid:18456252.

Coelho, M. S. Z. S., \& Massad, E. (2012). The impact of climate on Leptospirosis in São Paulo, Brazil. International Journal of Biometeorology, 56(2), 233-241. http://dx.doi. org/10.1007/s00484-011-0419-4. PMid:21369729.

Coelho, M. S. Z. S., Gonçalves, F. L. T., \& Latorre, M. R. D. O. (2010). Statistical analysis aiming at predicting respiratory tract disease hospital admissions from environmental variables in the city of São Paulo. Journal of Environmental and Public Health, 2010, 1-11. http:// dx.doi.org/10.1155/2010/209270. PMid:20706674.

Corburn, J. (2004). Confronting the challenges in reconnecting urban planning and public health. American Journal of Public Health, 94(4), 541-546. http://dx.doi.org/10.2105/ AJPH.94.4.541. PMid:15053998.

CRC for water sensitive cities. (2012). Project B3: water sensitive urban design and urban micro-climate. Clayton: CRC. Retrieved in 16 august 2015, from watersensitivecities. org.au
Doll, R., \& Hill, B. (1954). The mortality of doctors in relation to their smooking habits. British Medical Journal, 1(4877), 1451-1455.

Dora, C., Haines, A., Balbus, J., Fletcher, E., Adair-Rohani, H., Alabaster, G., Hossain, R., de Onis, M., Branca, F., \& Neira, M. (2015). Indicators linking health and sustainability in the post-2015 development agenda. Lancet, 385(9965), 380391. http://dx.doi.org/10.1016/S0140-6736(14)60605-X. PMid:24923529.

European Commission. (2015). Building a green for Europe environment infrastructure for Europe. Retrieved in 06 August 2015, from http://ec.europa.eu/environment/ nature/ecosystems/docs/green_infrastructure_broc.pdf

Fajersztajn, L., Veras, M., Barrozo, L. V., \& Saldiva, P. (2013). Air pollution: a potentially modifiable risk factor for lung cancer. Nature Reviews Cancer, 13(9), 674-678. http:// dx.doi.org/10.1038/nrc3572. PMid:23924644.

Ferri, R., Hashim, D., Smith, D. R., Guazzetti, S., Donna, F., Ferretti, E., Curatolo, M., Moneta, C., Beone, G. M., \& Lucchini, R. G. (2015). Metal contamination of home garden soils and cultivated vegetables in the province of Brescia, Italy: Implications for human exposure. The Science of the Total Environment, 518-519, 507-517. http://dx.doi. org/10.1016/j.scitotenv.2015.02.072. PMid:25777956.

Food and Agriculture Organization - FAO. (2014). Growing greener cities in Latin America and the Caribbean: a FAO report on urban and peri-urban agriculture in the region. Rome: FAO.

Freeman, M. C., Ogden, S., Jacobson, J., Abbott, D., Addiss, D. G., Amnie, G. A., Beckwith, C., Cairncross, S., Callejas, R., Colford Jr, J. M., Emerson, P. M., Fenwick, A., Fishman, R., Gallo, K., Grimes, J., Karapetyan, G., Keene, B., Lammie, P. J., MacArthur, C., Lochery, P., Petach, H., Platt, J., Prabasi, S., Rosenboom, J. W., Roy, S., Saywell, D., Lisa Schechtman, L., Tantri, A., Velleman, Y., \& Utzinger, J. (2013). Integration of water, sanitation, and hygiene for the prevention and control of neglected tropical diseases: a rationale for intersectoral collaboration. PLoS Neglected Tropical Diseases, 7(9), 1-9. http://dx.doi.org/10.1371/journal.pntd.0002439. PMid:24086781.

Freitas, E. D., Rozoff, C. M., Cotton, W. R., \& Dias, P. L. S. (2007). Interactions of an urban heat island and sea-breeze circulations during winter over the metropolitan area of São Paulo, Brazil. Boundary-Layer Meteorology, 122(1), 43-65. http://dx.doi.org/10.1007/s10546-006-9091-3 
Galea, S., Uddin, M., \& Koenen, K. (2011). The urban environment and mental disorders: epigenetic links. Epigenetics, 6(4), 400-404. http://dx.doi.org/10.4161/ epi.6.4.14944. PMid:21343702.

Galli, G., Nothomb, C., \& Baetings, E. (2014). Towards systemic change in urban sanitation (IRC Working Paper). The Hague: IRC. Retrieved in 15 May 2015, from http:// www.ircwash.org/sites/default/files/201411_wp_ towardssyschangeinurbansan_web.pdf

Gasparrini, A., Armstrong, B., Kovats, S., \& Wilkinson, P. (2012). The effect of high temperatures on cause specific mortality in England and Wales. Occupational and Environmental Medicine, 69(1), 56-61. http://dx.doi. org/10.1136/oem.2010.059782. PMid:21389012.

Gasparrini, A., Guo, Y., Hashizume, M., Lavigne, E., Zanobetti, A., Schwartz, J., Tobias, A., Tong, S., Rocklöv, J., Forsberg, B., Leone, M., De Sario, M., Bell, M. L., Guo, Y. L., Wu, C., Kan, H., Yi, S. M., Coelho, M. S. Z. S., Saldiva, P. H. N., Honda, Y., Kim, H., \& Armstrong, B. (2015). Mortality risk attributable to high and low ambient temperature: a multicountry observational study. Lancet, 386(9991), 369375. http://dx.doi.org/10.1016/S0140-6736(14)62114-0. PMid:26003380.

Gatto, N. M., Martinez, L. C., Spruijt-Metz, D., \& Davis, J. N. (2015). LA sprouts randomized controlled nutrition and gardening program reduces obesity and metabolic risk in latino youth. Obesity (Silver Spring, Md.), 23(6), 1244-1251. http://dx.doi.org/10.1002/oby.21077. PMid:25960146.

Grandjean, P., \& Landrigan, P. J. (2006). Developmental neurotoxicity of industrial chemicals. Lancet, 368(9553), 2167-2178. http://dx.doi.org/10.1016/S0140-6736(06)696657. PMid:17174709.

Guo, Y., Gasparrini, A., Armstrong, B., Li, S., Tawatsupa, B., Tobias, A., Lavigne, E., de Sousa Zanotti Stagliorio Coelho, M., Leone, M., Pan, X., Tong, S., Tian, L., Kim, H., Hashizume, M., Honda, Y., Guo, Y. L., Wu, C. F., Punnasiri, K., Yi, S. M., Michelozzi, P., Saldiva, P. H., \& Williams, G. (2014). Global variation in the effects of ambient temperature on mortality a systematic evaluation. Epidemiology (Cambridge, Mass.), 25(6), 781-789. http://dx.doi.org/10.1097/ EDE.0000000000000165. PMid:25166878.

Haines, A., McMichael, A. J., Smith, K. R., Roberts, I., Woodcock, J., Markandya, A., Armstrong, B. G., Campbell-Lendrum, D., Dangour, A. D., Davies, M., Bruce, N., Tonne, C., Barrett, M., \& Wilkinson, P. (2009). Public health benefits of strategies to reduce greenhouse-gas emissions: overview and implications for policymakers. Lancet, 374(9707), 21042114. http://dx.doi.org/10.1016/S0140-6736(09)61759-1 PMid:19942281.

Hara, Y., Tsuchiya, K., Matsuda, H., Yamamoto, Y., \& Sampei, Y. (2013). Quantitative assessment of the Japanese "local production for local consumption" movement: a case study of growth of vegetables in the Osaka city region. Sustainability Science, 8(4), 515-527. http://dx.doi. org/10.1007/s11625-012-0198-9

Harpham, T. (2009). Urban health in developing countries: what do we know and where do we go? Health \& Place, 15(1), 107-116.

Haynes, R. C. (2010). A worn-out welcome: renewed call for a global ban on asbestos. Environmental Health Perspectives, 118(7), 298-303. http://dx.doi.org/10.1289/ ehp.118-a298 PMid:20601321.

Hsieh, C. C., Chang, K., \& Kao, Y. (1999). Estimating the ozone formation potential of volatile aromatic compounds in vehicle tunnels. Chemosphere, 39(9), 1433-1444. http://dx.doi.org/10.1016/S0045-6535(99)00045-4. PMid:10481245.

Hu, F. B., Manson, J. E., \& Willett, W. C. (2001). Types of dietary fat and risk of coronary heart disease: a critical review. Journal of the American College of Nutrition, 20(1), 5-19. http://dx.doi.org/10.1080/07315724.2001.107190 08. PMid:11293467.

Instituto Brasileiro de Geografia e Estatística - IBGE. (2011). Pesquisa Nacional por Amostra de Domicilio 2001-2011. Rio de Janeiro; IBGE. Retrieved in 15 May 2015, from http:// seriesestatisticas.ibge.gov.br/series.aspx?vcodigo=PD276

Intergovernmental Panel on Climate Change - IPCC. (2013). Climate change 2013: the physical science basis. Contribution of working group I to the fifth assessment report of the intergovernmental panel on climate change. Cambridge: Cambridge University Press. Retrieved in 20 August 2015, from http://www.ipcc.ch/pdf/assessmentreport/ar5/wg1/WG1AR5_ALL_FINAL.pdf

International Agency for Research on Cancer - IARC. (2009). A review of human carcinogens Part C: arsenic, metals, fibres, and dusts (IARC Working Group on the Evaluation of Carcinogenic Risks to Humans). Lyon: IARC. Retrieved in 30 May 2015, from http://monographs.iarc.fr/ENG/ Monographs/vol100C/mono100C.pdf 
Kessler R. (2013). Urban gardening: managing the risks of contaminated soil. Environ Health Perspect, 121(1112), 326-333.

Khan, S. M., \& Simpson, R. W. (2001). Effect of a heat island on the meteorology of complex urban airshed. Boundary-Layer Meteorology, 100(3), 487-506. http:// dx.doi.org/10.1023/A:1019284332306.

Krieger, N. (2014). Urbanismo ecológico e equidade no domínio da saúde: uma perspectiva ecossocial. In Mostafavi, M. \& Doherty, G. Urbanismo ecológico (p. 518-519). São Paulo: Editora G. Gilli.

Laborde, A., Tomasina, F., Bianchi, F., Bruné, M. N., Buka, I., Comba, P., Corra, L., Cori, L., Duffert, C. M., Harari, R., Iavarone, I., McDiarmid, M. A., Gray, K. A., Sly, P. D., Soares, A., Suk, W. A., \& Landrigan, P. J. (2015). Children's health in Latin America: the influence of environmental exposures. Environmental Health Perspectives, 123(3), 201-210. PMid:25499717.

Laschewski, G., \& Jendritzky, G. (2002). Effects of the thermal environment on human health: an investigation of 30 years of daily mortality data from SW Germany. Climate Research, 21, 91-103.http://dx.doi.org/10.3354/cr021091.

Laumbach, R., \& Kipen, H. (2014). Mechanistic data support protecting non-smokers from the lethal effects of secondhand smoke. International Journal of Public Health, 59(4), 575-576. http://dx.doi.org/10.1007/s00038-014-0550-1. PMid:24781823.

Laverty, A. A., Palladino, R., Lee, J. T., \& Millett, C. (2015). Associations between active travel and weight, blood pressure and diabetes in six middle income countries: a cross-sectional study in older adults. The International Journal of Behavioral Nutrition and Physical Activity, 12(1), 65. http://dx.doi.org/10.1186/s12966-015-0223-3. PMid:25986001.

Lim, S. S., Vos, T., Lim, S. S., Vos, T., Flaxman, A. D., Danaei, G., Shibuya, K., Adair-Rohani, H., Amann, M., Anderson, H. R., Andrews, K. G., Aryee, M., Atkinson, C., Bacchus, L. J., Bahalim, A. N., Balakrishnan, K., Balmes, J., Barker-Collo, S., Baxter, A., Bell, M. L., Blore, J. D., Blyth, F., Bonner, C., Borges, G., Bourne, R., Boussinesq, M., Brauer, M., Brooks, P., Bruce, N. G., Brunekreef, B., Bryan-Hancock, C., Bucello, C., Buchbinder, R., Bull, F., Burnett, R. T., Byers, T. E., Calabria, B., Carapetis, J., Carnahan, E., Chafe, Z., Charlson, F., Chen, H., Chen, J. S., Cheng, A. T., Child, J. C., Cohen, A., Colson, K. E., Cowie, B. C., Darby, S., Darling, S., Davis, A., Degenhardt, L., Dentener, F., Des Jarlais, D. C., Devries, K., Dherani, M.,
Ding, E. L., Dorsey, E. R., Driscoll, T., Edmond, K., Ali, S. E., Engell, R. E., Erwin, P. J., Fahimi, S., Falder, G., Farzadfar, F., Ferrari, A., Finucane, M. M., Flaxman, S., \& Fowkes, F. G., Freedman, G., Freeman, M. K., Gakidou, E., Ghosh, S., Giovannucci, E., Gmel, G., Graham, K., Grainger, R., Grant, B., Gunnell, D., Gutierrez, H. R., Hall, W., Hoek, H. W., Hogan, A., Hosgood, H. D., Hoy, D., Hu, H., Hubbell, B. J., Hutchings, S. J., Ibeanusi, S. E., Jacklyn, G. L., Jasrasaria, R., Jonas, J. B., Kan, H., Kanis, J. A., Kassebaum, N., Kawakami, N., Khang, Y. H., Khatibzadeh, S., Khoo, J. P., Kok, C., Laden, F., Lalloo, R., Lan, Q., Lathlean, T., Leasher, J. L., Leigh, J., Li, Y., Lin, J. K., Lipshultz, S. E., London, S., Lozano, R., Lu, Y., Mak, J., Malekzadeh, R., Mallinger, L., Marcenes, W., March, L., Marks, R., Martin, R., McGale, P., McGrath, J., Mehta, S., Mensah, G. A., Merriman, T. R., Micha, R., Michaud, C., Mishra, V., Hanafiah, K. M., Mokdad, A. A., Morawska, L., Mozaffarian, D., Murphy, T., Naghavi, M., Neal, B., Nelson, P. K., Nolla, J. M., Norman, R., Olives, C., Omer, S. B., Orchard, J., Osborne, R., Ostro, B., Page, A., Pandey, K. D., Parry, C. D., Passmore, E., Patra, J., Pearce, N., Pelizzari, P. M., Petzold, M., Phillips, M. R., Pope, D., Pope, C. A., Powles, J., Rao, M., Razavi, H., Rehfuess, E. A., Rehm, J. T., Ritz, B., Rivara, F. P., Roberts, T., Robinson, C., Rodriguez-Portales, J. A., Romieu, I., Room, R., Rosenfeld, L. C., Roy, A., Rushton, L., Salomon, J. A., Sampson, U., Sanchez-Riera, L., Sanman, E., Sapkota, A., Seedat, S., Shi, P., Shield, K., Shivakoti, R., Singh, G. M., Sleet, D. A., Smith, E., Smith, K. R., Stapelberg, N. J., Steenland, K., Stöckl, H., Stovner, L. J., Straif, K., Straney, L., Thurston, G. D., Tran, J. H., van Dingenen, R., van Donkelaar, A., Veerman, J. L., Vijayakumar, L., Weintraub, R., Weissman, M. M., White, R. A., Whiteford, H., Wiersma, S. T., Wilkinson, J. D., Williams, H. C., Williams, W., Wilson, N., Woolf, A. D., Yip, P., Zielinski, J. M., Lopez, A. D., Murray, C. J., Ezzati, M., AlMazroa, M. A., \& Memish, Z. A. (2012). A comparative risk assessment of burden of disease and injury attributable to 67 risk factors and risk factor clusters in 21 regions, 1990-2010: a systematic analysis for the Global Burden of Disease Study 2010. Lancet, 380(9859), 2224-2260.

Ludwig, J., Duncan, G. J., Gennetian, L. A., Katz, L. F., Kessler, R. C., Kling, J. R., \& Sanbonmatsu, L. (2013). Long-term neighborhood effects on low-income families: evidence from Moving to Opportunity. American Economic Review, American Economic Association, 103(3), 226-231.

Marengo, J. A., Jones, R., Alves, L. M., \& Valverde, M. (2009). Future change of temperature and precipitation extremes in South America as derived from the PRECIS regional climate modeling system. International Journal of Climatology, 29(15), 2241-2255. http://dx.doi.org/10.1002/joc.1863. 
McMichael, A. J. (1996). Transport and health: assessing the risks. In T. Fletcher, \& A. J. McMichael (Eds.), Health at the crossroads: transport policy and urban health ( $\mathrm{p}$. 9-26). Chichester: John Wiley \& Sons.

Merzel, C. (2000). Gender differences in health care access indicators in an urban, low-income community. American Journal of Public Health, 90(6), 909-916. http://dx.doi. org/10.2105/AJPH.90.6.909. PMid:10846508.

Middle, I., Dzidic, P., Buckley, A., Bennett, D., Tye, M., \& Jones, R. (2014). Integrating community gardens into public parks: an innovative approach for providing ecosystem services in urban areas. Urban Forestry \& Urban Greening, 13(4), 638-645. http://dx.doi.org/10.1016/j.ufug.2014.09.001.

Milburn, L. S., \& Vail, B. A. (2010). Sowing the seeds of success: cultivating a future for community gardens. Landscape Journal, 29(1), 1-10. http://dx.doi.org/10.3368/ lj.29.1.71.

Mostafavi, M., \& Doherty, G. (2014). Urbanismo ecológico. São Paulo: Gustavo Gili.

Mueller, N., Rojas-Rueda, D., Cole-Hunter, T., Nazelle, A., Dons, E., Gerike, R., Götschi, T., Panis, L. I., Kahlmeier, S., \& Nieuwenhuijsen, M. (2015). Health impact assessment of active transportation: A systematic review. Preventive Medicine, 76, 103-114. http://dx.doi.org/10.1016/j. ypmed.2015.04.010. PMid:25900805.

Nawrot, T.S., Perez, L., Künzli, N., Munters, E., \& Nemery, B. (2011). Public health importance of triggers of myocardial infarction: a comparative risk assessment. Lancet, 377(9767), 732-740.

Newman, P., \& Kenworthy, G. (1999). Cities and sustainability: reducing auto dependency. Washington, D.C.: Island Press.

O’Reilly, K. M. A., McLaughlin, A. M., Beckett, W. S., \& Sime, P. J. (2007). Asbestos-related lung disease. American Family Physician, 75(5), 683-688. PMid:17375514.

Ollila, E. (2011). Health in all policies: from rhetoric to action. Scandinavian Journal of Public Health, 39(6, Suppl.), 11-18. http://dx.doi.org/10.1177/1403494810379895. PMid:20813799.

Pan American Health Organization - PAHO. (2013). WHOAIMS: report on mental health systems in Latin America and the Caribbean. Washington, D.C: PAHO.

Peen, J., Schoevers, R. A., Beekman, A. T., \& Dekker, J. (2010). The current status of urban-rural differences in psychiatric disorders. Acta Psychiatrica, 121(2), 84-93.
Pucher, J., \& Buehler, R. (2007). At the frontiers of cycling: policy innovations in the Netherlands, Denmark, and Germany. World Transport Policy and Practice, 13, 9-56.

Pucher, J., \& Buehler, R. (2008). Making cycling irresistible: lessons from the Netherlands, Denmark and Germany. Transport Reviews, 28(4), 495-528. http://dx.doi. org/10.1080/01441640701806612.

Rissel, C. E. (2009). Active travel: a climate change mitigation strategy with co-benefits for health. New South Wales Public Health Bulletin, 20(1-2), 10-13. http://dx.doi.org/10.1071/ NB08043. PMid:19261210.

Rydin, Y., Bleahu, A., Davies, M., Dávila, J. D., Friel, S., De Grandis, G., Groce, N., Hallal, P. C., Hamilton, I., HowdenChapman, P., Lai, K., Lim, C. J., Martins, J., Osrin, D., Ridley, I., Scott, I., Taylor, M., Wilkinson, P., \& Wilson, J. (2012). Shaping cities for health: complexity and the planning of urban environments in the 21st century. Lancet, 379(9831), 2079-2108. http://dx.doi.org/10.1016/S01406736(12)60435-8. PMid:22651973.

Saldiva, P. (2010). 0 homem e o meio ambiente urbano. In Saldiva, P. \& Vormittag, E. M. P. A. A. Meio ambiente e saúde: o desafio das metrópoles (p. 18-20). São Paulo: ExLibris Comunicação Integrada.

Saldiva, P. H. N., King, M., Delmonte, V. L. C., Macchione, M., Parada, M. A. C., Daliberto, M. L., Sakae, R. S., Criado, P. M. P., Parada, P. L. P., Zin, W. A., \& Böhm, G. M. (1992). Respiratory alterations due to urban air pollution: an experimental study in rats. Environmental Research, 57(1), 19-33. http://dx.doi.org/10.1016/S0013-9351(05)800167. PMid:1371246.

Saunders, L. E., Green, J. M., Petticrew, M. P., Steinbach, R., \& Roberts, H. (2013). What are the health benefits of active travel? A systematic review of trials and cohort studies. PLoS One, 8(8), 1-13.

Sebrié, E. M., Schoj, V., \& Glantz, S. A. (2008). Smoke free environments in Latin America: on the road to real change? Prevention and Control, 3(1), 21-35. http://dx.doi. org/10.1016/j.precon.2007.09.001. PMid:19578527.

Shiue, I., \& Shiue, M. (2014). Indoor temperature below $18{ }^{\circ} \mathrm{C}$ accounts for $9 \%$ population attributable risk for high blood pressure in Scotland. International Journal of Cardiology, 171(1), e1-e2. http://dx.doi.org/10.1016/j. ijcard.2013.11.040. PMid:24315341.

Silva Dias, M. M. F., Dias, J., Carvalho, L. M. V., Freitas, E. D., \& Silva Dias, P. L. (2013). Changes in extreme daily rainfall 
for São Paulo, Brazil. Climatic Change, 116(3-4), 705-722. http://dx.doi.org/10.1007/s10584-012-0504-7.

Smith, K. R., Frumkin, H., Balakrishnan, K., Butler, C. D., Chafe, Z. A., Fairlie, I., Kinney, P., Kjellstrom, T., Mauzerall, D. L., McKone, T. E., McMichael, A. J., \& Schneider, M. (2013). Energy and human health. Annual Review of Public Health, 34(1), 159-188. http://dx.doi.org/10.1146/annurevpublhealth-031912-114404. PMid:23330697.

Smith, K. R., McCracken, J. P., Weber, M. W., Hubbard, A., Jenny, A., Thompson, L. M., Balmes, J., Diaz, A., Arana, B., \& Bruce, N. (2011). Effect of reduction in household air pollution on childhood pneumonia in Guatemala (RESPIRE): a randomised controlled trial. Lancet, 378(9804), 17171726. http://dx.doi.org/10.1016/S0140-6736(11)60921-5. PMid:22078686.

Snyder, R. E., Jaimes, G., Riley, L. W., Faerstein, E., \& Corburn, J. (2014). A comparison of social and spatial determinants of health between formal and informal settlements in a large metropolitan setting in Brazil. Journal of Urban Health, 91(3), 432-445. http://dx.doi.org/10.1007/s11524-0139848-1. PMid:24297475.

Sobral, R. H. (2005). Heat Island in São Paulo, Brazil. Critical Public Health, 15(2), 147-156. http://dx.doi. org/10.1080/09581590500151756.

Solecki, W. D., Rosenzweig, C., Parshall, L., Popec, G., Clarkc, M., Coxa, J., \& Wiencked, M. (2005). Mitigation of the heat island effect in urban New Jersey. Global Environmental Change Part B: Environmental Hazards, 6(1), 39-49.

Souza, E. L. L., \& Macedo, I. (2010). Etanol e bioeletricidade: a cana-de-açucar no futuro da matriz energética. São Paulo: União da Indústria de Cana-de-Açúcar.

Swinton, S. M., Lupi, F., Robertson, G. P., \& Hamilton, S. K. (2007). Ecosystem services and agriculture: cultivating agricultural ecosystems for diverse benefits. Ecological Economics, 64(2), 245-252. http://dx.doi.org/10.1016/j. ecolecon.2007.09.020.

Tan, J., Zheng, Y., Tang, X., Guo, C., Li, L., Song, G., Zhen, X., Yuan, D., Kalkstein, A. J., Li, F., \& Chen, H. (2010). The urban heat island and its impact on heat waves and human health in Shanghai. International Journal of Biometeorology, 54(1), 75-84. http://dx.doi.org/10.1007/s00484-009-0256-x. PMid:19727842.

Thomson, H., Thomas, S., Sellstrom, E., \& Petticrew, M. (2013). Housing improvements for health and associated socioeconomic outcomes. Cochrane Database of Systematic Reviews, 2, CD008657.

Tohill, B. C., Seymour, J., Serdula, M., Kettel-Khan, L., \& Rolls, B. J. (2004). What epidemiologic studies tell us about the relationship between fruit and vegetable consumption and body weight. Nutrition Reviews, 62(10), 365-374. http://dx.doi.org/10.1111/j.1753-4887.2004.tb00007.x. PMid:15508906.

Torreggiani, D., Dall'Ara, E., \& Tassinari, P. (2012). The urban nature of agriculture: bidirectional trends between city and countryside. Cities (London, England), 29(6), 412-416. http://dx.doi.org/10.1016/j.cities.2011.12.006.

United Nations - UN. (2010). The human right to water and sanitation. Resolution adopted by the General Assembly. Zaragoza: United Nations. Retrieved in 2 May 2015, from http://www.un.org/es/comun/docs/?symbol=A/ RES/64/292\&lang=E

United States Environment Protection Agency - EPA. (2006). Excessive heat events guidebook. Washington, D.C: EPA. Retrieved in 15 April 2015, from www.epa.gov/hiri/ about/pdf/EHEguide_final.pdf

United States Environmental Protection Agency - EPA. (2014). Green infrastructure. Washington, D.C: EPA. Retrieved in 15 August 2015, from water.epa.gov/infrastructure/ greeninfrastructure

Urban, A., Davídkovová, H., \& Kyselý, J. (2014). Heatand cold-stress effects on cardiovascular mortality and morbidity among urban and rural populations in the Czech Republic. International Journal of Biometeorology, 58(6), 1057-1068. http://dx.doi.org/10.1007/s00484013-0693-4. PMid:23793998.

Vahlsing, C., \& Smith, K. R. (2012). Global review of national ambient air quality standards for PM10 and SO2 (24 h). Air Quality, Atmosphere \& Health, 5(4), 393-399. http:// dx.doi.org/10.1007/s11869-010-0131-2. PMid:23205158.

Wang, X., \& Zhang, Y. (2009). A new method for determining the initial mobile formaldehyde concentrations, partition coefficients, and diffusion coefficients of dry building materials. Journal of the Air \& Waste Management Association, 59(7), 819-825. http://dx.doi.org/10.3155/1047-3289.59.7.819 PMid:19645266.

Warming, M., Hansen, M. G., Holm, P. E., Magid, J., Hansen, T. H., \& Trapp, S. (2015). Does intake of trace elements through urban gardening in Copenhagen pose a risk to 
human health? Environmental Pollution, 202, 17-23. http:// dx.doi.org/10.1016/j.envpol.2015.03.011 PMid:25796073.

Watts, N., Adger, W. N., Agnolucci, P., Blackstock, J., Byass, P., Cai, W., Chaytor, S., Colbourn, T., Collins, M., Cooper, A., Cox, P. M., Depledge, J., Drummond, P., Ekins, P., Galaz, V., Grace, D., Graham, H., Grubb, M., Haines, A., Hamilton, I., Hunter, A., Jiang, X., Li, M., Kelman, I., Liang, L., Lott, M., Lowe, R., Luo, Y., Mace, G., Maslin, M., Nilsson, M., Oreszczyn, T., Pye, S., Quinn, T., Svensdotter, M., Venevsky, S., Warner, K., Xu, B., Yang, J., Yin, Y., Yu, C., Zhang, Q., Gong, P., Montgomery, H., Costello, A. (2015). Health and climate change: policy responses to protect public health. Lancet, 386(10006), 1861-1914.

Weich, S., Lewis, G., \& Jenkins, S. (2001). Income inequality and the prevalence of common mental disorders in Britain. The British Journal of Psychiatry, 178(3), 222-227. http:// dx.doi.org/10.1192/bjp.178.3.222 PMid:11230032.

Wilkinson, P., Smith, K. R., Davies, M., Adair, H., Armstrong, B. G., Barrett, M., Bruce, N., Haines, A., Hamilton, I., Oreszczyn, T., Ridley, I., Tonne, C., \& Chalabi, Z. (2009). Public health benefits of strategies to reduce greenhouse-gas emissions: household energy. Lancet, 374(9705), 1917-1929. http:// dx.doi.org/10.1016/S0140-6736(09)61713-X PMid:19942273.

Wolch, J. R., Byrne, J., \& Newell, J. P. (2014). Urban green space, public health, and environmental justice: the challenge of making cities 'just green enough'. Landscape and Urban Planning, 125, 234-244. http://dx.doi.org/10.1016/j. landurbplan.2014.01.017

World Health Organization - WHO. (2004). Urban bioclimatology in health and global environmental change.
Retrieved in 30 November 2009, from http://www.euro. who.int/globalchange

World Health Organization - WHO. (2011). Health in the green economy: health co-benefits of climate change mitigation: transport sector. Geneva: WHO. Retrieved in 7 November 2012, from http://www.who.int/hia/examples/ trspt_comms/hge_transport_lowresdurban_30_11_2011.pdf

World Health Organization - WHO. (2014a). Social determinants of mental health. Geneva: WHO.

World Health Organization - WHO. (2014b). 7 million premature deaths annually linked to air pollution. Geneva: WHO. Retrieved in 5 November 2014, from http://www.who. int/mediacentre/news/releases/2014/air-pollution/en/

World Health Organization/United Nations Children's Fund - WHO/UNICEF. (2014). Progress on drinking water and sanitation: 2014 update. Geneva: WHO/UNICEF. Retrieved in 2 May 2015, from http://www.who.int/ water_sanitation_health/publications/2014/jmp-report/en/

World Health Organization/United Nations Children's Fund - WHO/UNICEF. (2015). Improved and unimproved water sources and sanitation facilities. Geneva: WHO. Retrieved in 2 May 2015, from http://www.wssinfo.org/ definitions-methods/watsan-categories/

Zezza, A., \& Tasciotti, L. (2010). Urban agriculture, poverty, and food security: empirical evidence from a sample of developing countries. Food Policy, 35(4), 265-273. http:// dx.doi.org/10.1016/j.foodpol.2010.04.007

Received: June 15, 2015

Approved: Oct. 05, 2015 


\section{Errata}

In the article "How can ecological urbanism promote human health?", DOI number: 10.1590/2175-3369.008.001. SE05, published in urbe - Brazilian Journal of Urban Management, 8(1): 77-95, on page 77:

Where it reads:

"Micheline de Souza Zanotti Staglionario Coelho"

It should read:

"Micheline de Souza Zanotti Stagliorio Coelho" 